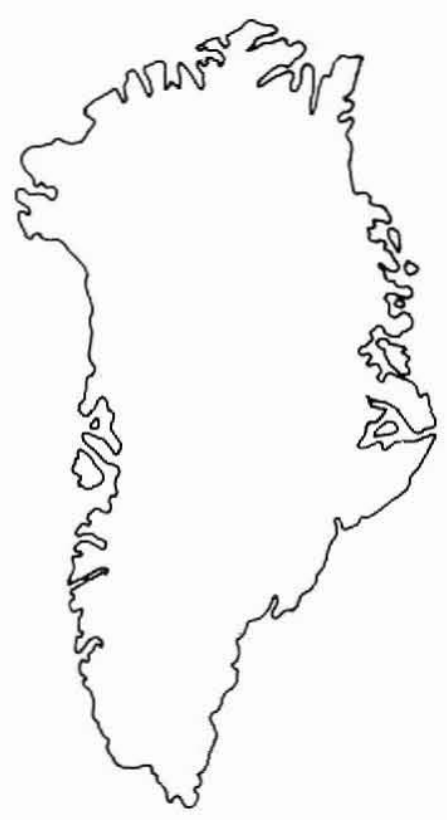

\section{An application of multi-model photogrammetry in the study of a Tertiary shale unit, north-east Disko, West Greenland}

\author{
Gunver Krarup Pedersen
}

\begin{abstract}
Multi-model photogrammetry has been applied in a study of the lateral continuity of lithofacies in a dark grey shale unit on the north-east coast of Disko. The shale is $c .60$ $\mathrm{m}$ thick and can be traced laterally for 12 kilometres. It is demonstrated that a distinct sand-streaked shale facies as well as contrasting thin pale sand units can be mapped confidently and that very accurate sections can be measured where the photogrammetric conditions are optimal.
\end{abstract}

G. K. P., Geological Institute, University of Copenhagen, Øster Voldgade 10, DK-1350 Copenhagen K, Denmark.
The study of thick shale units requires field work in two different scales: a millimetre to centimetre scale for recognition of lamination types and a $10 \mathrm{~m}$ to kilometre scale for the lateral tracing of shale facies. Detailed studies of the lamination in shales focus on subtle variations in colour, grain-size and composition and these variations are often best seen in cores. In outcrops the presence or absence of lamination is often obscured by the fissility, which is a product of diagenesis and weathering. However, thin layers of contrasting lithologies (tuff layers or small concretions) interbedded in shale can readily be seen in good outcrops, particularly steep slopes or stream sections where scree is no problem.

On the basis of the presence or type of lamination, shale sequences can generally be divided into a number of facies that often form units a few to ten metres thick and laterally continuous over hundreds of metres. Field work on shale sequences should therefore ideally combine detailed observations of selected sections with a regional study of the shale facies. The aims of the present study are (1) to demonstrate the use of multi-model photogrammetry in the lateral tracing of shale facies, and (2) to try to establish the scale of sedimentary features that can be recognised in the photographs.

A Paleocene, lacustrine shale unit, c. $60 \mathrm{~m}$ thick, is exposed over a distance of $12 \mathrm{~km}$ from Pingo to Nuugaarsuk in north-eastern Disko (Figs 1, 2). The shale unit is intercalated in a c. $500 \mathrm{~m}$ thick series of unconsolidated Tertiary sand which can be correlated to parts of

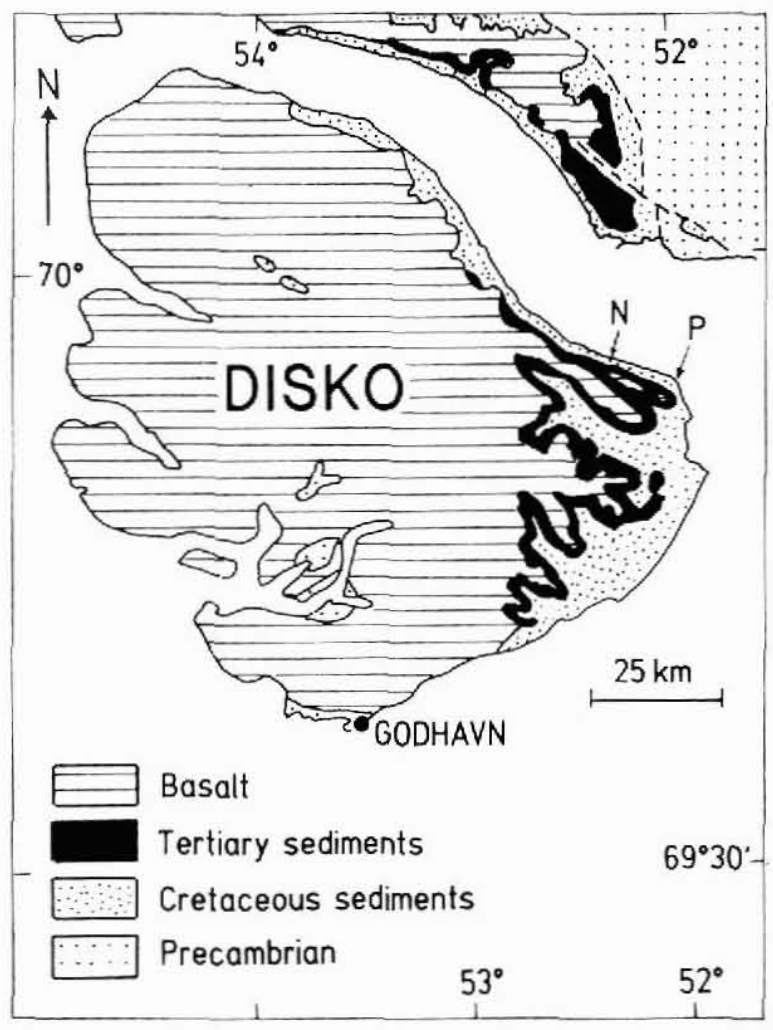

Fig. 1. Geological location map of Disko showing the studied section between Pingo (P) and Nuugaarsuk (N) and the position of the Tertiary sediments between Cretaceous sediments and Tertiary volcanic rocks. 


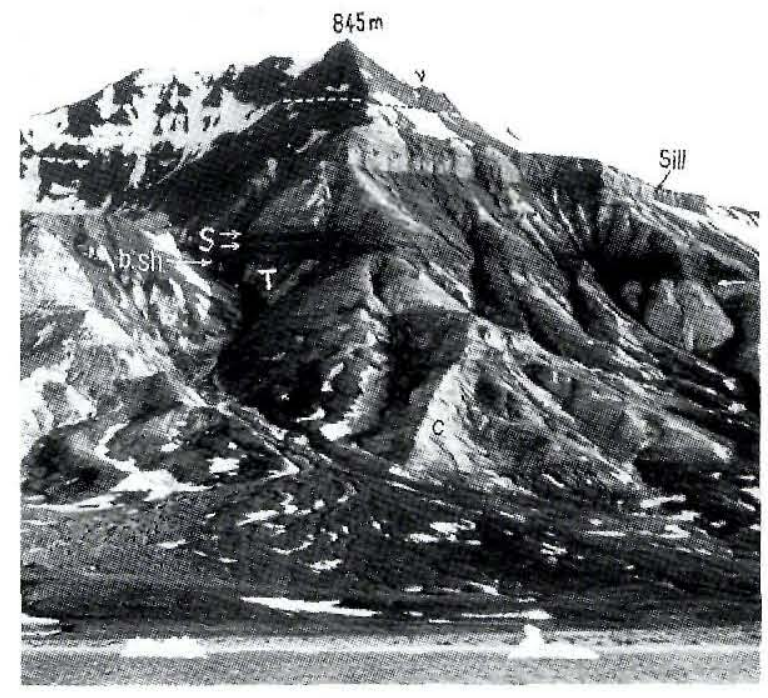

Fig. 2. The dark grey shale unit studied is seen as a continuous $60 \mathrm{~m}$ thick horizon on the north-east slope of Pingo. The base of the shale unit (b.sh.) is indicated (arrows). The thin sand units are marked (s). The shale unit overlies Tertiary sand (T) and Cretaceous sand (C). Pingo is capped by volcanics (v).

the Upper Atanikerdluk Formation (Koch, 1959). This formation rests unconformably on the Cretaceous deltaic Atane Formation in Nuussuaq and in the studied section the Tertiary sediments are capped by volcanic rocks of the Maligât Formation (Larsen \& Pedersen, 1990). The shale unit includes a number of thin tuff layers as well as thin sand layers. A photogrammetrically measured section is compared with a section studied in the field and lithological boundaries have been traced photogrammetrically.

\section{Lithology}

The studied unit is dominated by grey to dark grey silty shale underlain and overlain by Tertiary fluvial sand. The lower boundary is sharp whereas the upper boundary is transitional (Figs 3,4). The shale is micaceous and may contain comminuted plant debris but it is mineralogically dominated by quartz and kaolinite. Bands of $1-3 \mathrm{~cm}$ thick sideritic concretions can be traced for hundreds of metres. A number of tuff layers occur, which are $0.5-3 \mathrm{~cm}$ thick and weather in whitish and brownish colours. Some of the tuff layers are confidently recognised through most outcrops, whereas others lack distinctive characters that permit identification and correlation. The dominant facies in the shale unit is a structureless to weakly laminated shale with an irregular fissility.

Sand-streaked shale constitutes a characteristic part of the unit, and this facies is recognised at a distance because it produces a much steeper slope than usual (Fig. 3). The sand-streaked shale has a distinct lamination. The upper part of the shale unit is heterolithic, characterised by an alternation between shale and thin beds of sand. The sand is fine-grained, often parallel laminated, and thin drapes of coalified plant debris may be seen on bedding planes or in ripple-troughs in crosslaminated sand. Upwards through the unit the sand
Fig. 3. The lacustrine shale sequence at Pingo where the sedimentological log (Fig. 4B) was measured. Note the lateral continuity of the distinct thin sand units (s) in the middle of the section (mapped in Fig. 4A). The lower boundary is sharp (b.sh.) while the upper one is transitional. The tuff layers ( $t$ ) are not clearly seen. The sand-streaked shale is indicated (s.sh.).

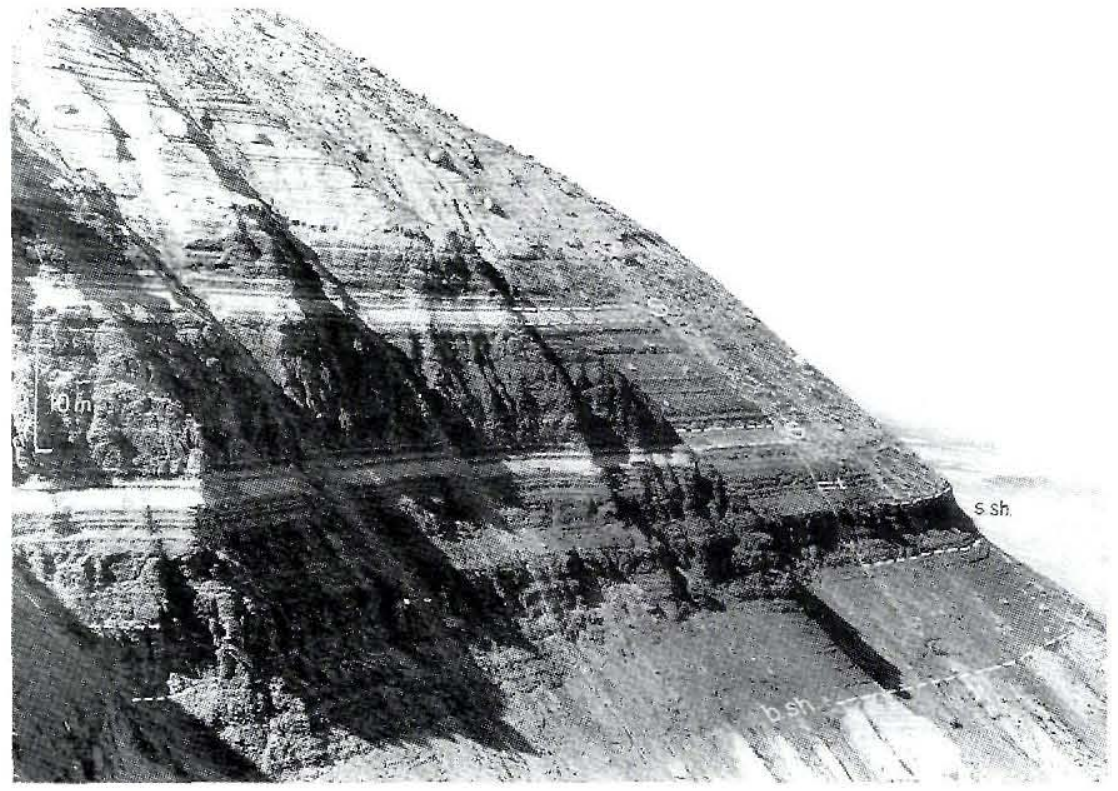



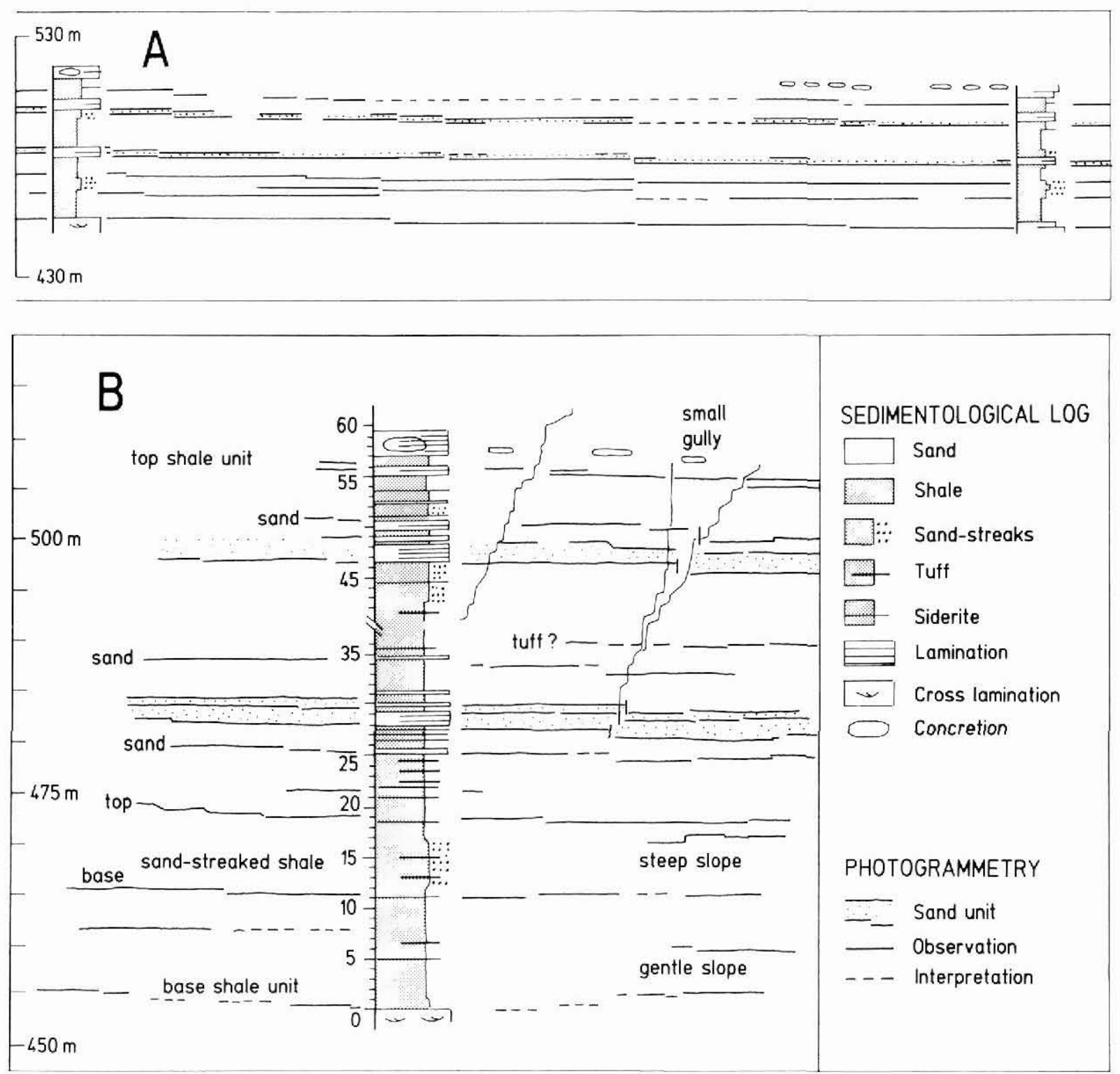

Fig. 4. (A) Interpretation of the shale sequence at Pingo based on multi-model photogrammetry (five stereo-pairs). The log to the left is shown in greater detail in Fig. 4B. (B) A single photogrammetric model in which many details can be measured. For comparison a sedimentological $\log$ measured in the field is inserted. There is a good match between the log and the photogrammetric section in the top and bottom of the shale sequence, whereas the sedimentological log shows an excess of $2 \mathrm{~m}$ of shale between 35 and $46 \mathrm{~m}$. These two 'extra' metres have been left sut in the log (Fig. 4B) in order to make easier the comparison between the sedimentological log and the photogrammetric section.

layers increase in thickness and frequency, and the shale passes transitionally into the overlying sand (Pedersen, 1989).

The shale contains no pyrite and no dinoflagellates, whereas c. 60 species of terrestrial spores and pollen have been identified (Hjortkjær, 1991). The shale unit can probably be correlated with shale units devoid of dinoflagellates in Frederik Langes Dal and Kvandalen (Piasecki et al., 1992: loc. 1, m). The shale is therefore interpreted as lacustrine (Pedersen, 1989) and it has been dated as middle Paleocene (Hjortkjær, 1991). The assemblage of spores and pollen is uniform throughout the studied shale sequence, which suggests that the shale was deposited fairly rapidly (Hjortkjær, 1991). 
The formation of the lake is probably linked to the magmatic phase which led to the formation of the volcanic Rinks Dal Member and to the associated block faulting (Piasecki et al., 1992). The lake presumably attained its greatest depth initially and was gradually infilled by fine-grained sediment. The syn-sedimentary volcanism is reflected in the tuff layers. These are thickest in the eastern part of the shale unit, at Pingo, and decrease in thickness westwards, indicating that the eruptive centre was located relatively far to the east. The distribution of the tuff in addition to the composition indicate that the tuff layers should be correlated to the lower part of the volcanic Rinks Dal Member of the Maligât Formation (A. K. Pedersen, personal communication, 1991).

\section{Photogrammetry}

In order to test the possibility of tracing details within the shale unit the necessary photographs were taken at close distance $(c .500 \mathrm{~m})$ from a helicopter with a Hasselblad SWC camera ( $40 \mathrm{~mm}$ lens). The photoscale is approximately 1:12 000. The close distance from which the photographs were taken meant that certain outcrops were at an advantageous angle to the photographer, whereas others were photographed under more oblique angles. The amount of light varied strongly in and between the many small gullies which characterise the studied area, which generally faces north-east. Fine details are visible in those stereomodels where the outcrops are well lighted and the angle of photography is optimal. Figure 4 illustrates photogrammetric measurements of such outcrops and it is seen that the accuracy, if not the detail, rivals that of a manually produced sedimentological log.

The shale unit at Pingo starts with a basal part consisting of fairly homogeneous shale with few tuff layers $(0-11 \mathrm{~m}$ in Fig. 4B). This is overlain by the sandstreaked shale $(12-17 \mathrm{~m})$ which has the same colour but weathers to steeper slopes. The first test of the photogrammetric method was therefore the recognition of the sand-streaked shale. This shale facies can be traced laterally for $450 \mathrm{~m}$ in Fig. $4 \mathrm{~A}$ and for kilometres in stereomodels which are not shown. The next part of the sequence comprises shale with several tuff layers (20-25 $\mathrm{m}$ in Fig. 4B). It was possible to trace certain tuff layers over short distances but the confidence in tuff layer recognition is low. Certain 'layers' recognised could not be matched with observed tuff layers. Above the middle of the shale unit two prominent sand units are seen, each composed of several thinner, graded beds of fine sand ( $28-30 \mathrm{~m}$ and $46-51 \mathrm{~m}$ in Fig. 4B). These whitish sand units form a strong contrast to the shale and they are very easily recognised in the photographs. The upper part of the shale unit is heterolithic $(53-57 \mathrm{~m}$ in Fig. 4B) and the boundary to the overlying fluvial sand is transitional.

\section{Discussion}

The present study, which is still preliminary in character, has shown that multi-model photogrammetry is an attractive approach to the study of thicker shale units. As boundaries and marker horizons are mapped photogrammetrically, the field work can be concentrated to the best outcrops which show those details that are beyond the resolution of the photographs. The difficulty in multi-model photogrammetry of shale sequences lies in reaching a compromise between the scale of the photographs and the minimum thickness of the beds to be studied. As the multi-model photogrammetric method can switch between photographs at various scales and angles of view it is recommended that stereoseries of photographs at small scale, which are less sensitive to variations in light and angle of photography are combined with close-up photographs of those outcrops where light and photographic angle are optimal. Under optimal photographic conditions even very fine details in good exposures on steep slopes may be measured with an accuracy that frequently cannot be achieved in the field.

\section{Conclusions}

Multi-model photogrammetry can be used as a control of thicknesses measured in the field. The photogrammetric method also provides a very precise correlation between sedimentological logs through shale sequences characterised by lateral continuation of individual facies. Multi-model photogrammetry thereby facilitates the rapid mapping of stratigraphic units dominated by shale.

Acknowledgements. Field work was financed by the National Science Research Council (grants 11-6350 and 11-6973) and the Geological Survey of Greenland. A. K. Pedersen took the photographs and K. Dueholm introduced me to the photogrammetric interpretation at Institut for Landmåling og Fotogrammetri, DTH. The manuscript was improved by helpful comments from the referee. I direct my best thanks to these persons and institutions.

\section{References}

Hjortkjær, B. F. 1991: Palynologisk undersøgelse af tertiære skifre fra Disko og Nûgssuaq, Vestgrønland. Unpublished thesis, University of Copenhagen, $94 \mathrm{pp}$. 
Koch, B. E. 1959: Contribution to the stratigraphy of the non-marine Tertiary deposits on the south coast of the Nûgssuaq Peninsula, Northwest Greenland. Meddr Grønland 162 (1), $100 \mathrm{pp}$.

Larsen, L. M. \& Pedersen, A. K. 1990: Volcanic marker horizons in the Maligat Formation on Disko and Nûgssuaq, and implications for the development of the southern part of the West Greenland basin in the early Tertiary. Rapp. Grønlands geol. Unders. 148, 65-73.
Pedersen, G. K. 1989: A fluvial-dominated lacustrine delta in a volcanic province, W Greenland. In Whateley, M. K. G. \& Pickering, K. T. (ed.) Deltas: sites and traps for fossil fuels. Spec. Publ. geol. Soc. London 41, 139-146.

Piasecki, S., Larsen, L. M., Pedersen, A. K. \& Pedersen, G. K. 1992: Palynostratigraphy of the Lower Tertiary volcanics and marine clastic sediments in the southern part of the West Greenland basin: implications for the timing and duration of the volcanism. Rapp. Grønlands geol. Unders. 154, 13-31. 